\title{
From Language Learners to Language Teachers to Language Teacher Trainers: Narrative Stories of Four Instructional Coaches
}

\author{
Chin-Wen Chien ${ }^{1}$ \\ ${ }^{1}$ Department of English Instruction, National Hsinchu University of Education, Taiwan \\ Correspondence: Chin-Wen Chien, Department of English Instruction, National Hsinchu University of \\ Education, Hsinchu 300, Taiwan. Tel: 886-3-5213132 ext.6712. E-mail: chinwenc@ms24.hinet.net
}

Received: August 19, 2014 Accepted: September 20, 2014 Online Published: October 23, 2014

doi:10.5539/elt.v7n11p53 URL: http://dx.doi.org/10.5539/elt.v7n11p53

\begin{abstract}
This study discusses how four instructional coaches' roles and identities, as well as the school district context, have influenced their development as instructional coaches. This study thematically analyzes the narrative stories of four elementary school English instructional coaches in New Taipei City, Taiwan. The study concludes that the way they have been taught to learn English has influenced the way they themselves teach English, which in turn has influenced the areas of expertise they have focused on as instructional coaches. The schools and the district where these instructional coaches teach have had a direct impact on their roles as language teachers and language teacher trainers.
\end{abstract}

Keywords: identity, instructional coach, language learner, language teacher, language teacher trainer, narrative story

\section{Introduction}

Language teacher research has focused on understanding that language teachers are and their roles (Varghese, 2007). Connelly and Clandinin (1990) stated that work on teachers' stories helps promote the legitimacy of narrative in the study of teaching. They further proposed that professional identity can be characterized as "stories to live by" and referred to it as "a way to conceptually bring together a teacher's personal practical knowledge, his or her professional knowledge landscape and identity" (p. 25). The practice of teaching is constructed when teachers tell and live out particular stories (Elbaz-Luwisch, 2002).

Scholars in Taiwan have studied the operations, functional development, services, challenges, and the evaluation criteria of instructional coaches and instructional supervision groups in different subject areas. Cheng (2002) discussed elementary school English instructional coaching in terms of its organization and operation, and the services provided, but did not focus on coaches' identities and social contexts. Narrative inquiry is a way of thinking about and studying experience (Connelly \& Clandinin, 2006). Language teachers have been shaped by on the sociopolitical context surrounding the teachers. Narrative inquiry has been widely used in investigations of language teacher identities because it plays a key role in understanding teachers' roles, identities and experiences (Varghese, 2007).

The Ministry of Education (MoE) in Taiwan has implemented the Nine-Year Curriculum for six-year elementary school and three-year junior high school students since the commencement of the academic year in 2000. In order to put the Nine-Year Curriculum successfully into practice in elementary and junior high school education, the MoE has formed elementary and junior high school Nine-Year Curriculum Instructional Supervision Groups under the Bureau of Education for each of the local governments. The curriculum for elementary school education is divided into subject areas which include languages (Mandarin Chinese, dialects, and English), math, science and technology, social studies, integrative courses, health and physical education, and arts and humanities. The remits of the elementary school Nine-Year Curriculum Instructional Supervision Groups are also divided according to the different subject areas. The Elementary School English Instructional Supervision Group (ESEISG) is one of such groups in New Taipei City. Members of the ESEISG in Taiwan play similar roles to English instructional coaches in the United States. In this article, these group members are referred to as 'English instructional coaches'.

The job of the English instructional coaches is to give English teachers in elementary schools guidance on the 
curriculum, teaching materials, teaching methods, and assessments. It is expected by the MoE that English teaching will be made more effective and teaching quality will be improved as a result of the guidance provided by the English instructional coaches. The responsibilities of the English instructional coaches in New Taipei City include the following: to attend a weekly committee meeting; to ensure the implementation of the educational policies; to hold at least one seminar per year; to hold at least ten hour-long workshops for English teachers; and to submit personal portfolios (Cheng, 2002; Chien, 2010).

Any elementary school English teacher who meets the following qualification requirements can apply to be an English instructional coach: they must be current English teachers with at least two years of teaching experience, hold a bachelor's degree and have enthusiasm as well as adequate stamina and fortitude to perform the role. Former instructional coaches must submit their personal portfolio and attend an oral interview (Chien, 2010). New applicants must submit a personal portfolio, give a ten-minute teaching demonstration, and then undergo an oral interview (Chien, 2010). They themselves are language learners and language teachers, but now they are granted a new identity as "language teacher trainers."

Four instructional coaches who share their experience of progress from language learners to language teachers, and then to language teacher trainers participated in this study. The study aims to discuss how these four participants' roles and identities, as well as the school district context, have influenced their development as instructional coaches.

\section{Literature Review}

The literature review in this study focuses on narrative and instructional coaches.

\subsection{Narrative}

Narrative is one of the most popular ways of representing and understanding the experience of language learning and teaching (Bell, 2002; Clandinin \& Connelly, 2000; Connelly \& Clandinin, 1999, 2006). Narrative inquiry has gained popularity in language teacher education (Johnson \& Golombek, 2002; Pavlenko, 2011; Tsui, 2007) because it has the potential to provide explanations of how teachers' knowledge is constructed (Cochran-Smith \& Lytle, 2009). Narrative research involves making meaning. Barkhuizen's (2011) concept of "narrative knowledge" refers to "meaning making, learning, and knowledge construction that takes place at all stages of a narrative research project" (p. 395).

Analysis of narrative stories can offer teacher educators glimpses into the processes of professional development as they unfold (Nelson, 2011; Vasquez, 2011). Johnson and Golombek (2002) propose that narrative stories function in terms of knowledge-building and professional development. Johnson and Golombek (2002) claim that the products of teachers' narrative activities function as a tool for knowledge-building within SLTE [second language teacher education] when they are made public, open to review by others, and accessible to others in the profession through engagement with wider professional discourses and practices (p. 502).

Beijaard, Meijer, and Verloop (2004) point out that "Through storytelling, teachers engage in narrative 'theorizing' and, thus, teachers may further discover and shape their professional identity, resulting in new or different stories" (p. 121). Barkhuizen's (2010) study uses positioning analysis of a small story about Sela, a migrant, pre-service EFL teacher in Tonga. To answer the question "Who am I?" and in reading Barkhuizen's analysis, Sela can retell her experience of becoming a language teacher by repositioning and reimagining her own teacher identity. The narrative analysis reveals that Sela "positioned herself as complicit with a dominant English language teacher ideology, expressed particularly as an economic metaphor of investment, capitalization, and a better life" (p. 15).

\subsection{Instructional Coaches}

Most studies undertaken in Taiwan on elementary school instructional coaches in different subjects have focused on instructional coaches' organization and operation, and on functional developments, services, challenges, and evaluation criteria (Chen, 2007; Chi, 2007; Chu, 2007; Hsiao, 2007; Lai, 2006; Liu, 2006; Tang, 2008; Ting, 2007; M. H. Tsai, 2004; W. F. Tsai, 2004; Tu, 2006; Yu, 2006). Cheng (2002) also focuses on instructional coaches' development but this study did not focus on their identities or on social contexts.

Knight (2009) identifies the factors influencing the roles of instructional coaches including job descriptions and role expectations, goals, and context (e.g., time of the school year, whether new to a school, the coaches' and teachers' experience level, the role of the principal, and the school culture). Professional identity implies both the person and the context, because teachers, who work within their own school culture and context, may develop their own teaching identity and culture (Beijaard, Meijer, \& Verloop 2004; Beijaard, Verloop, \& Vermunt, 2000). Coaching has been shown to be influenced by other components of a larger reform effort and by educational 
policies (Taylor, 2008).

\section{Method}

This is a qualitative narrative study. This study aims to discuss the following questions: First, what roles and identities did the instructional coaches perceive themselves? Second, why did the instructional coaches have particular perceptions of their roles and their identity? Third, how do the roles of language learners and language teachers influence the roles of instructional coaches as language teacher trainers?

\subsection{Data Collection}

Narrative stories of four instructional coaches comprise the data of this study. The researcher was appointed as an instructional coach for four years in New Taipei City. She contacted the instructional coaches and invited them to participate in this study. Four female instructional coaches had time to participate in this study. These four instructional coaches signed an informed consent and they ensured that they were placed in a situation where they decided, in full knowledge of the risks and benefits of the study, whether and how to participate. . Their names and schools are not disclosed in the study. They were asked to orally share the stories on the journey from being language learners, to language teachers, to language teacher trainers.

\subsection{Research Setting and Participants}

Table 1 shows these four participants' demography. In order to become an elementary school English teacher in Taiwan, one of the following criteria must be met: to (1) have passed the MoE's 1999 Elementary School English Teachers' Qualification Exam; (2) have a university degree with a major or minor in English; (3) have an English proficiency level equivalent to upper intermediate in terms of the Common European Framework of Reference for Languages; (4) have taken an elementary school English teacher twenty-credit course program; (5) have completed a post-graduate level elementary school English teacher education program; or (6) have completed an English major at university with a minor in education. The four participants of this study became English teachers having met different criteria. Lily passed the MoE's 1999 Elementary School English Teachers' Qualification Exam and completed educational and English teaching courses in two years. Carol majored in languages at a university for teachers with a minor in English. Linda passed the Test of English as Foreign Language (TOEFL) test and had an English proficiency level equivalent to upper intermediate in terms of the Common European Framework of Reference for Languages. Linda and Wendy both took an elementary school English teacher twenty-credit course program offered by the local government.

Table 1. Demography of instructional coaches

\begin{tabular}{llllll}
\hline Names & Linda & Lily & Carol & Wendy & \\
\hline English teacher criteria & $(3)(4)$ & $(1)$ & $(2)$ & $(4)$ & \\
Teaching years & 20 & 12 & 12 & 17 & \\
Education & M.A. in & M.A. in & M. A. in Children & M. A. in Educational \\
Years of being a coach & 5 & 5 & 10 & 8 & \\
\hline
\end{tabular}

Linda has taught for 20 years and the others have a minimum of 12 years of teaching experience. All of them have a master's degree in language or education. While Linda and Carol have a master's degree in TESOL and children's English education respectively, Lily has her master's degree in Spanish. Wendy has her master's degree in educational communication and technology and her thesis focused on elementary school English instruction on sight words. Carol has the longest coaching experience and she has been an instructional coach for almost ten years, including two years as a central government instructional coach. The others have served as instructional coaches for at least five years.

\subsection{Data Analysis}

A set of codes was constructed to capture the meanings expressed by the data. The data was coded in the following three stages. First, the researcher read through all the notes and marked the data by a code (e.g., language learner, language teacher, language teacher trainer, etc.). Secondly, while reading through these codes, the researcher assigned tentative categories (e.g., role, expertise, identity, challenges etc.). Finally, the data were sorted on the basis of fit into topics that reflected the research questions. Member checking was used to assure 
the aspects of trustworthiness. When the instructional coaches shared their narrative stories, member checking consisted of the researcher restating, summarizing, or paraphrasing the information received from a respondent to ensure that what was heard or written is in fact correct. Following the data collection, the researcher did member checking by reporting back preliminary findings to participants, asking for critical commentary on the findings, and potentially incorporating these critiques into the findings.

\section{Findings and Discussions}

York-Barr and Duke (2004) identified three categories of conditions that influence instructional coaches: school cultures and context, roles and relationships, and structures. Their roles and identity, schools, and districts influence how they act as instructional coaches. The findings on instructional coaches' narrative stories are discussed in terms of their intertwined roles, their motivation for being instructional coaches, the attitudes they have about their roles and identity, and the challenges they face.

\subsection{Intertwined Roles}

The way instructional coaches were taught as language learners has influenced the way they have taught English in the elementary school. Moreover, the way they have taught English in elementary schools has in turn affected how they have specialized in coaching areas.

While Carol's specialties are in songs and chants as well as pronunciation, Wendy's expertise is in reading and writing.

Carol: Since childhood, I began to listen to western songs with my elder brother. I learn to pronounce English words through songs. When I was in the junior high school, my English teacher first taught letter names and letter sounds of the 26 [letter] alphabet. She emphasized accurate pronunciation and giving students successful experience. Now I spend a lot of time teaching pronunciation and the 26 letters of the alphabet to the beginning learners. As an instructional coach, I have to deliver professional development or workshops; my specialties are "songs and chants" and "pronunciation."

Wendy: English seemed very abstract to me when I began to learn it in senior high school. The teacher emphasized a lot of grammar and reading. I have made a good habit of reading English books and magazines. I am good at English reading and writing, so these are two areas I focus on a lot in my teaching. I work on these two topics when I give a speech at English teachers' workshops about professional development.

Wenger (1998) claims that "we define who we are by the ways we experience ourselves through participation as well as by the ways we and other reify ourselves" (p. 149).

As EFL teachers, Linda and Lily identify the biggest problem in learning English in Taiwan as "not knowing how to use English" as follows:

Linda: The biggest problem in learning English in Taiwan is a lack of situations where I can use English, particularly in speaking and writing. Taiwan is an EFL context. The problem is not how to learn English, but how to use English. Now as a language teacher, I always focus on how to turn the inputs into outputs and create simulations for my learners.

Lily: The teachers I like the most are those who are loving and caring. When I first attended an English conversation class, I couldn't answer the teacher's simple question, "How are you?" I felt so awful, but the teacher didn't scold me and he gave me more chances. So I love and care about my students and I don't push them to speak English when they are not ready. I will wait.

Taiwanese English teachers, as non-native English speaking teachers, are at an advantage in elementary school English education (Liao, 2004; Wang, 2008). These teachers have a deep cultural understanding and empathy as they know their students' English learning difficulties because they have gone through a similar process and learning path, as Lily described her embarrassing experience in a conversation class.

Moreover, Lily was able to apply the strategies that she had learned in English to learning Spanish. So as an EFL teacher, she highlights the learning strategy instruction in her classes.

Lily: I learned Spanish through comparing and contrasting the differences and similarities between English and Spanish. Now when I teach, I help my students compare and contrast between English and Chinese.

Lily can easily apply her English learning strategies to learning Spanish. She can also help her learners compare the similarities and differences between English and Chinese in terms of pronunciation and grammar because she is fluent in both Chinese and English. Taiwanese English teachers know their students' learning backgrounds and needs. They can provide appropriate learning materials and methods to suit the students (Department of 
Education, Taipei City Government, 2006; Wang, 2008). Therefore, Johnson and Golombek (2002) regard narrative as systematic examination as follows: "By design, they embody particular set of parameters that encourage language teachers to engage in systematic examinations of themselves, their teaching practices, and the historical, cultural, social, political contexts that constitute their professional worlds in particular ways" (pp. 492-493).

These instructional coaches' involvement in telling their stories helped them reflect on their prior language learning experiences, critically analyze these experiences, and relate their analysis to their perception of both language learning and teaching. Therefore, the products of these narrative stories become tools for knowledge-building and expanding the professional landscape of language teacher education (Johnson \& Golombek, 2011).

\subsection{Motivation for Being an Instructional Coach}

The first time that these four instructional coaches had experience of other instructional coaches was at the workshops. They all had a positive attitude toward the instructional coaches and admired their expertise. There were three major reasons why these four participants wanted to become instructional coaches. First, they wanted to be outstanding like the instructional coaches. Wendy said, "All instructional coaches are experts and knowledgeable. I want to be like them." Lily worked on her doctoral degree, but could not continue due to a family crisis. She desperately wanted professional growth. Being knowledgeable about language acquisition and content areas is one of the characteristics of the instructional coach (Davis, 2008). Carol and Lily were motivated to become instructional coaches because they both aspired to professional growth and had expertise in the field of English language teaching.

Second, through recommendation by other instructional coaches, Carol became an instructional coach because of her excellent teaching demonstration in the workshop.

Carol: I met instructional coaches when I received my sixty-hour English teaching training. On the last day of the training, each group had to give a teaching demonstration. I was the novice teacher, so I gave a teaching demonstration. The instructional coach thought my teaching was great, so they invited me to be an instructional coach.

Davis (2008) identifies one characteristic of an instructional coach as being someone who is capable of modeling lessons for teachers in front of students they have never met. Carol was chosen because administrators look for good teachers to coach and model lessons for others.

Third, no support and professional growth were provided in these participants' original schools. Teachers at their schools expected stability, and it appears that they did not want to improve, particularly at Wendy and Lily's schools.

Wendy: My school is like an ivory tower. I did not want to be limited and confined to the school alone. I am enthusiastic about teaching English, but the rest of the teachers are not. I want to go beyond the school's environment and I want to broaden my views.

Lily: I don't like my colleagues. I don't like the school's atmosphere. They don't care about teaching. They just want to teach routinely without any innovation. I am tired of this.

Lily and Wendy fell into "experimentation/diversification" in the typical sequence of the teacher career cycle. Having worked with six to seven year cohorts of students, and having associated with the same teacher peers, they began to repeat the yearly cycle and to find, over time, that this lacked variation. Thus they needed stimulation, new ideas, challenges, and engagements (Huberman, 1995).

\subsection{Attitude toward Their Roles and Identity}

The four participants hold positive attitudes about being instructional coaches and none of them feel that their expertise as instructional coaches is challenged by other elementary school English teachers, as is shown in the following:

Wendy: No teachers challenged my expertise. I share with them what I have done in my school and in classes. During the curriculum evaluation visit, compared to elementary school principals and university professors, elementary school English teachers felt that I could offer them more help.

Wendy's concept of an instructional coach's expertise concurred with what the literature puts forward as "be[ing] expert classroom teacher" and "possess[ing] in-depth knowledge of teaching processes, acquisition, assessment, and instruction" (International Reading Association, 2004, p. 10). The teachers often discover that the suggestions made by instructional coaches are useful because instructional coaches provide methods for 
balancing theory and creativity with hands-on experimentation and structure (Davis, 2008; Kise, 2006; Read, 2008; Reiss, 2007). In this study, the English instructional coaches are experts in elementary school English education who can provide assistance to small groups of teachers in order to improve classroom practice and student achievement.

They feel like working as a team and being supported by other instructional coaches.

Wendy: What I like the most about being an instructional coach is having the support and the intimacy. Other instructional coaches are open and willing to share.

Lily: I like my team and I learn a lot from my team members. The reason why I continue to be an instructional coach is because I have support from my team.

One of the characteristics that instructional coaches should have is to be capable of building trusting relationships and fostering a collaborative culture and environment (Davis, 2008; Martin-Kniep, 2008). Under such environment, these instructional coaches create positive working relationships, support one another, and share their thoughts. They create a sense of community identity and gain ongoing professional learning through sharing new information and techniques.

Moreover, they feel that their English language teaching improves greatly, as follows:

Wendy: I don't think I would improve greatly if I were in my school. Being an instructional coach, I have many opportunities for professional growth. A regular English teacher can attend only one training [session] offered by the American School in Taipei. I attended at least four times, because I worked as a teacher's assistant there.

Lily: I like to give speech and share my ideas with other English teachers. I like to interact with other English teachers during the workshops.

Carol: My classroom practice helps me a lot in being an instructional coach, because I can share practical and useful instructional strategies and activities with other English teachers. At the same time I can improve my own teaching.

An important approach to enhancing teacher learning is to develop communities of practice; this involves collaborative peer relationships and teachers' participation in educational research and practice. In these communities, teachers share successes and failures with pedagogy and lesson planning (National Research Council, 2000). The instructional coaches in this study felt that they had improved their teaching by sharing their classroom practice with other English teachers and instructional coaches. Being an instructional coach provided the participants with opportunities to acquire new information and learn new strategies, to come up with creative lesson plans, and to increase their "bag of tricks". Therefore, sharing and reflection seem to provide an effective channel for exploring the situated and intricate process of acquiring expertise (Orland-Baraka \& Yinon, 2005).

\subsection{Challenges as Instructional Coaches}

The four participants identified four challenges they had faced as instructional coaches. First, they lacked training on how to coach others or how to design and deliver professional development to English teachers.

Carol: I did not receive any training while being an instructional coach. I was forced to give a speech to English teachers. The government has begun to provide training on how to give a speech in 2011. In my opinion, instructional coaches should be trained how to be instructional coaches and how to effectively coach other teachers.

In addition to being expert classroom teachers and being equipped with an in-depth knowledge of instruction, instructional coaches must be excellent presenters and have experience of working with teachers to improve their instructional practice (International Reading Association, 2004). Taylor (2008) suggests that there are at least two components of the training for coaches. First, instructional coaches must have adequate knowledge of effective curriculums and methods of instruction. Second, they must learn adult learning theories, present professional development, use student performance data, develop collegial support, and tailor their work to meet teachers' needs. Moreover, instructional coaches should be trained to lead effective coaching conversations (Cheliotes \& Reilly, 2010; Lipton \& Wellman, 2007). Teacher leaders should encourage professional growth by engaging with colleagues in positive conversations with a clear focus on their classroom practice in a psychologically safe environment, and by differentiating support, so that such conversations can lead to action, stimulate teachers' growth, and result in change (Cheliotes \& Reilly, 2010; Lipton \& Wellman, 2007).

The second challenge they face is to propagandize English education policies that they disagree with, so their professional identity is challenged. 
Lily: Teachers doubt my identity as an instructional coach. They said to me, "As an English teacher, you know the governmental policies are not reasonable. You should stop the implementation of policies." But being an instructional coach, I couldn't confront the Government; instead I have to propagandize English education policies. My relationship with some English teachers has changed, not that close.

Scholars point out that the sociocultural and political context plays a key role in shaping teacher identity (Duff \& Uchida, 1997; He, 2002). Instructional coaches, who are one kind of teacher leader, often experience difficulty in switching roles between teacher and leader (LeBlanc \& Shelton, 1997; York-Barr \& Duke, 2004). Instructional coaches like Lily sometimes disagree with some of the educational policies, but they have no other choice but to promote them because they were appointed by the educational bureaus. Their role as instructional coaches affects their relationship with other English teachers in their own schools and district. York-Barr and Duke (2004) state that "A negative effect of these relationship shifts can be a sense of greater distance from and even a loss of specific, valued relationship with colleagues" (p. 283).

The third challenge is that instructional coaches sometimes spend too much time on administrative work, and not enough on coaching. They also have to ask official leave to attend meetings and, when they cannot teach some of their classes, substitute teachers are hired to teach for them. They feel that their students' rights are being sacrificed.

Lily: It's a pity that we are not involved in coaching teachers. We don't have time to visit English teachers, observe their teaching, and provide them with feedback and guidance.

Wendy: We spend too much time on administrative work such as being a judge of contests, or designing standardized tests.

Carol: When we design and deliver professional development, we should be responsible for giving the speeches. However, we have to work on administrative work such as being responsible for signing up. Administrators should undertake the minor or administrative tasks.

Linda: My students complain that they miss me a lot, because I have to take official leave. My school is lucky to be able to find qualified and responsible substitute teachers. I carefully design the lessons and explain all the teaching procedures to the substitute teachers before taking the leave. My students still prefer my teaching.

Coaches have many roles to play in their profession. The amount of time they spend in one role may affect the amount of time they can devote to other roles. York-Barr and Duke (2004) discuss dimensions of the roles of teacher leaders including coordination and management, school or district curriculum work, professional development of colleagues, participation in school change, parent and community involvement, and contributions to the profession and pre-service teacher education. Regardless of what roles an instructional coach plays, Knight (2009) further discusses factors that influence the balance of these roles, including job descriptions and role expectations, goals, and context (e.g., time of the school year, coach's experience, expectations of the principal, school culture). Bean (2004) identifies three levels of activities associated with the coaches. Level one activities include informal activities such as curriculum development or leading a study group. Level two activities are focused on area needs such as co-planning lessons, co-teaching lessons, or analyzing student work. Level three activities include visiting classrooms and providing teachers with feedback. Because these instructional coaches spend a large amount of time in dealing with management issues for the district office, they are unable to devote much time to Bean's (2004) level I and II activities.

\section{Conclusions}

This study focuses on how the instructional coaches' intertwined roles, their schools, and the district contexts influence their coaching practice, as depicted in Figure 1. The findings of this study are as follows: First, the four participants' intertwined roles as language learners and language teachers have influenced their roles as instructional coaches. The way they have been taught to learn English has influenced the way that they themselves have taught English, which in turn has influenced the areas of expertise they have focused on as instructional coaches. 


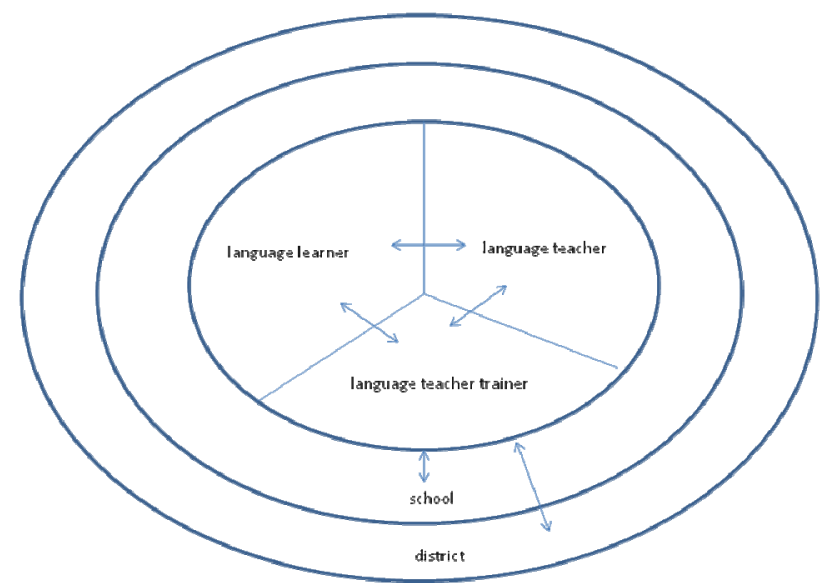

Figure 1. Roles and contexts of instructional coaches

Second, in terms of the school context, the schools where these instructional coaches teach have had an impact on their roles as language teachers and language teacher trainers. However, instructional coaches have to rely on the administrative support from their own schools and find qualified and responsible substitute English teachers when they have to take official leave to undertake coaching tasks, in order that their students' English learning will not be affected by their absence from school.

Third, their roles as instructional coaches are affected by the district contexts. Lacking training on how to coach, taking on too much administrative work, and propagandizing English education policies that they disagree with affect their professional identity as language teacher trainers when they serve as instructional coaches.

Two suggestions are made by the researcher to make coaching more effective. First, the professional development of instructional coaches should be designed and workshops on how to coach should be delivered before teachers take up their roles as instructional coaches. Ongoing professional development should be provided in the areas of coaching conversation, curriculum and instruction, and adult learning theories. Second, instructional coaches should spend more time visiting English teachers, planning and setting teachers' individual professional development goals, designing actions, monitoring progress, and celebrating success. Instructional coaches should establish a safe environment for teachers to acquire new knowledge, including the study of the theory, the observation of demonstrations, practice in protected conditions, and observation of one another (Richards \& Farrell, 2005).

Learning is situated in social contexts rather than individual acquisition of abstract concepts from interaction and experience (Franson \& Holliday, 2009; Freeman, 1995). Singh and Richards (2006) argue that teacher identity and teacher learning are formed and embedded socially. These four instructional coaches' knowledge, identity, and beliefs have been constructed and shaped through the professional learning in a larger community. They, as language teachers, can integrate and apply their professional learning and knowledge into their classroom instruction to see if they are effective classroom professionals. Therefore, they, as language teacher trainers, can share their professional learning with other language teachers.

The instructional coaches' language learning experiences and English teaching backgrounds may have had an impact on their roles as language teacher trainers, as depicted in Figure 1 above. The four participants in this study became English teachers because they met one of the criteria mandated by the MoE. However, none of the participants became English teachers because they had completed a postgraduate level elementary school English teacher education program, or because they had achieved an English major at university with a minor in education. A further study could focus on instructional coaches who meet these two criteria, and consider how their English education training backgrounds and language learning experiences have influenced their roles as language teacher trainers.

\section{References}

Barkhuizen, G. (2010). An extended positioning analysis of a pre-service teacher's better life small story. Applied Linguistics, 31(2), 282-300. http://dx.doi.org/ 10.1093/applin/amp027

Barkhuizen, G. (2011). Narrative knowledge in TESOL. TESOL Quarterly, 45(3), 391-414. http://dx.doi.org/ 10.5054/tq.2011.261888 
Bean, R. M. (2004). Promoting effective literacy instruction: The challenge for literacy coaches. The California Reader, 37(3), 58-63.

Beijaard, D., Verloop, N., \& Vermunt, D. J. (2000). Teachers' perceptions of professional identity: An exploratory study from a personal knowledge perspective. Teaching and Teacher Education, 16(7), 749-764. http://dx.doi.org/ 10.1016/S0742-051X(00)00023-8

Beijaard, D., Meijer, P. C., \& Verloop, N. (2004). Reconsidering research on teachers' professional identity. Teaching and Teacher Education, 20(2), 107-128. http://dx.doi.org/ 10.1016/j.tate.2003.07.001

Bell, J. S. (2002). Narrative research in TESOL. TESOL Quarterly, 36(2), 207-213. http://dx.doi.org/10.2307/ 3588331

Cheliotes, L. G., \& Reilly, M. F. (2010). Coaching conversation: Transforming your school one conversation at a time. Thousand Oaks, CA: Corwin.

Chang, C. F. (2007). Research on organizational operations and performance of Taipei County compulsory education advisory group of the domain of natural science and life technology (Unpublished master's thesis). National Taipei University of Education, Taipei, Taiwan.

Cheng, T. Y. (2002). The function and organization of elementary school English instructional supervision group: A study of Taipei County English instructional supervision group (Unpublished master's thesis). National Taipei University of Education, Taipei, Taiwan.

Chi, L. Y. (2007). Implementation of environmental education at elementary schools and the operation of environmental education advisory groups (Unpublished master's thesis). National Taipei University of Education, Taipei, Taiwan.

Chien, C. W. (2010). Elementary school English instructional supervision group: Its challenges and new directions. In B. Snyder (Ed.), Advancing ELT: Empowering teachers, empowering learners (pp. 303-308). Proceedings of the $14^{\text {th }}$ Annual KOTESOL International Conference, Seoul, Korea.

$\mathrm{Chu}$, J. F. (2007). The research on operation strategies of the Hualien County compulsory advisory group (Unpublished master's thesis). National Hualien University of Education, Hualien, Taiwan.

Clandinin, D. J., \& Connelly, F. M. (2000). Narrative inquiry: Experience and story in qualitative research. San Francisco, CA: Jossey-Bass.

Cochran-Smith, M., \& Lytle, S. (2009). Inquiry as stance: Practitioner research for the next generation. New York, NY: Teachers College Press.

Connelly, F. M., \& Clandinin, D. J. (1990). Stories of experience and narrative inquiry. Educational Researcher, 19(5), 2-14. http://dx.doi.org/ 10.3102/0013189X019005002

Connelly, F. M., \& Clandinin, D. J. (1999). Shaping a professional identity: Stories of education practice. London, ON: Althouse Press.

Connelly, F. M., \& Clandinin, D. J. (2006). Narrative inquiry. In J. Green, G. Camilli, \& P. Elmore (Eds.), Handbook of complementary methods in education research (pp 375-385). Mahwah, NJ: Lawrence Erlbaum.

Davis, B. (2008). How to coach teachers who don't think like you. Thousand Oaks, CA: Corwin Press.

Department of Education, Taipei City Government. (2006). Needs for native speaking English teachers and recruiting models in elementary schools in Taipei City. Taipei, Taiwan: Author.

Duff, P., \& Uchida, Y. (1997). The negotiation of teachers' sociocultural identities and practices in postsecondary EFL classrooms. TESOL Quarterly, 31(3), 451-486. http://dx.doi.org/ 10.2307/3587834

Elbaz-Luwisch, F. (2002). Writing as inquiry: Storying the teaching self in writing workshops. Curriculum Inquiry, 32(4), 403-428. http://dx.doi.org/ 10.1111/1467-873X.t01-1-00239

Franson, C., \& Holliday, A. (2009). Social and cultural perspective. In A. Burns, \& J. C. Richards (Eds.), The Cambridge guide to second language teacher education (pp. 40-46). New York, NY: Cambridge University Press.

Freeman, D. (1995). "Good" questions: Perspectives from qualitative research on practice, knowledge, and understanding in teacher education. TESOL Quarterly, 29(3), 581 -585. http://dx.doi.org/10.2307/3588077

He, M. F. (2002). A narrative inquiry of cross-cultural lives: Lives in the North American academy. Journal of 
Curriculum Studies, 34(3), 513-533. http://dx.doi.org/10.1080/00220270110114090

Hsiao, S. F. (2007). Study on the operation of the counseling organization in the arts and humanities of nine-year education (Unpublished master's thesis). National Taiwan Normal University, Taipei, Taiwan.

Huberman, M. (1995). Professional careers and professional development: Some intersections. In T. Guskey, \& M. Huberman (Eds.), Professional development in education (pp. 193-224). New York, NY: Teachers College Press.

International Reading Association. (2004). Best practice brief: The reading coach. Newark, DE: Author.

Johnson, K., \& Golombek, P. R. (2002). Teachers' narrative inquiry as professional development. Cambridge, UK: Cambridge University Press.

Johnson, K., \& Golombek, P. (2011). The transformative power of narrative in second language teacher education. TESOL Quarterly, 45(3), 469-485. http://dx.doi.org/ 10.5054/tq.2011.256797

Kise, J. (2006). Differentiated coaching: A framework for helping teachers change. Thousand Oaks, CA: Corwin Press.

Knight, J. (2009). Coaching: Approaches and perspectives. Thousand Oaks, CA: Corwin Press.

Lai, J. F. (2006). A research of constructing operation evaluation indicator and the current condition of compulsory education advisory group (Unpublished master's thesis). National Sun Yat-Sen University, Kaohsiung, Taiwan.

LeBlanc, P. R., \& Shelton, M. M. (1997). Teacher leadership: The needs of teachers. Action in Teacher Education, 19(3), 32-48. http://dx.doi.org/10.1080/01626620.1997.10462877

Liao, B. S. (2004). English as a global language and its effects on Taiwan's English education. English Teaching and Learning, 29(1), 107-121.

Lipton, L., \& Wellman, B. (2007). How to talk so teachers listen. Educational Leadership, 65(1), 30-34.

Liu, C. Y. (2006). The study on professional functions of integrative activities compulsory education advisory group: Taking a county in southern part of Taiwan as example (Unpublished master's thesis). National Chiayi University, Chiayi, Taiwan.

Martin-Kniep, G. O. (2008). Developing learning communities through teacher expertise. Thousand Oaks, CA: Corwin Press.

National Research Council. (2000). How people learn: Brain, mind, experience, and school. Washington, DC: National Academy Press.

Nelson, C. (2011). Narratives of classroom life: Changing conceptions of knowledge. TESOL Quarterly, 45(3), 463-485. http://dx.doi.org/ 10.5054/tq.2011.256799

Orland-Barak, L. (2006). Convergent, divergent and parallel dialogues: knowledge construction in professional conversations. Teachers and Teaching: Theory and Practice, 12(1), 13-31. http://dx.doi.org/ $10.1080 / 13450600500364547$

Pavlenko, A. (2002). Narrative study: Whose story is it, anyway? TESOL Quarterly, 36(2), 213-218. http://dx.doi.org/10.2307/3588332

Read, F. (2008). The impact of the sheltered instruction observation protocol (SIOP) on the instructional practices of elementary school teachers and on the reading achievement of English language learners (Unpublished doctoral dissertation). Wilmington University, Delaware.

Reiss, K. (2007). Leadership coaching for educators. Thousand Oaks, CA: Corwin Press.

Richards, J., \& Farrell, T. (2005). Professional development for language teachers. New York, NY: Cambridge University Press.

Singh, G., \& Richards, J. (2006, April). Teaching and learning in the language teacher education course room: A critical socio-cultural perspective. Paper presented at the RELC International Conference on Teacher Education in Language Teaching, Singapore.

Tang, P. M. (2008). The study of connotation for professional role and recognition development of full-time counselor in county/city compulsory education advisory group (Unpublished master's thesis). National Taiwan Normal University, Taipei, Taiwan.

Taylor, J. (2008). Instructional coaching: The state of the art. In M. M. Mangin, \& S. R. Stoelinga (Eds.), 
Effective teacher leadership: Using research to inform and reform (pp. 10-35). New York, NY: Teachers College Press.

Ting, T. C. (2007). A Study of the Mathematics Learning Area Compulsory Education Advisory Group's Organization and Efficiency in Pingtung County (Unpublished master's thesis). National Pingtung University of Science and Technology, Pintung, Taiwan.

Varghese, M. M. (2007). Language Teacher Research Methods. In Volume Ten (ed. K. King) of the Encyclopedia of Language and Education (2nd ed. General editor, N. Hornberger, pp. 287-298). Heidelberg, Germany: Springer.

Tsai, M. H. (2004). A study of organizational operation and functional development for compulsory education advisory group in Taipei City (Unpublished master's thesis). National Taipei University of Education, Taipei, Taiwan.

Tsai, W. F. (2004). A study on the organization and operation of instruct guiding team in nine-jointed healthy and physical education learning area (Unpublished master's thesis). National Pingtung University of Education, Pingtung, Taiwan.

Tsui, A. B. M. (2007). Complexities of identity formation: A narrative inquiry of an EFL teacher. TESOL Quarterly, 41(4), 657-680. http://dx.doi.org/10.1002/j.1545-7249.2007.tb00098.x

Tu, Y. M. (2006). A study of the operation and dilemma of the Chinese language guidance group: An example of elementary education instructional supervision group in Hualien (Unpublished master's thesis). National Hualien University of Education, Hualien, Taiwan.

Varghese, M. M. (2007). Language teacher research methods. In K. King (Ed.), The encyclopedia of language and education (pp. 287-298). Heidelberg, Germany: Springer.

Vásquez, C. (2011). TESOL, teacher identity, and the need for "small story" research. TESOL Quarterly, 45(3), 535-545. http://dx.doi.org/10.5054/tq.2011.256800

Wang, Y. H. (2008). The teaching behavior differences between native and non-native English speaking teachers: A case study at public primary school in Taiwan (Unpublished master's thesis). National Taiwan University of Science and Technology, Taipei, Taiwan.

Wenger, E. (1998). Communities of practice: Learning, meaning and identity. Cambridge, UK: Cambridge University Press.

York-Barr, J., \& Duke, K. (2004). What do we know about teacher leadership? Findings from two decades of scholarship. Review of Educational Research, 74(3), 255-316. http://dx.doi.org/10.3102/00346543074003255

Yu, M. W. (2006). A study on learning motivation and satisfaction with the Consulting group's school service of the integrative activities subject by the elementary school teachers in Changhua County (Unpublished master's thesis). National Changhua Normal University, Chunghua County, Taiwan.

\section{Copyrights}

Copyright for this article is retained by the author(s), with first publication rights granted to the journal.

This is an open-access article distributed under the terms and conditions of the Creative Commons Attribution license (http://creativecommons.org/licenses/by/3.0/). 